(c) 1991 ISI.J

\section{解 説}

湿式法による金属あるいは金属酸化物 超微粒子の製造とその表面特性

\section{村 松 淳 可*.佐々木弘*}

\title{
Production of Metallic and Oxide Ultrafine Particles in Liquid-phase and Their Surface Characteristics
}

Atsushi Muramatsu and Hiroshi SaSAKI

\section{1. は じめに}

阔体が微粘化すると特異な物理化学:的挙動を振る舞う ことから超微䊀子は物理兴的あるいは化学的関心を集め ているが, 门業的利用は現段階ではかなり限られている. 最も重要な丁業的忍用のひとつが磁性材料, 特にコン ピューターの発展と问時に技術革新の著しい磁気テープ や磁気ディスクへの伈用であろう。この超微粒子という ことばが登場したのは20年ほど前であるが, 液体中に 超微䊀子あるいは微䊀子が分散している、コロイド（ヒ ドロゾル）に関する議論はそれこそ 100 年以、の歴史 があり、ことさら超微档子に関する研究を行っていると いう認識もこの分野では少ない。1述の磁気ディスクに 塗布する磁性材料もこのコロイド化学:の手法老忍用した ものである。この磁性材料の製造については他の解説 ${ }^{11}$ もあり、ここでは触れない。

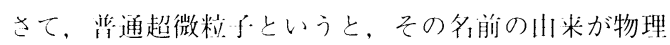
去さんから来ているためか, 金属超微档子、それもガス 中蒸発法などのいわゆる乾式のお法で周成されたものに 限定さ机るケースが多い．そのため多くの研究者がコロ イドの中にも超微䊀子と恋起できるような大きさの料子 が多く含まれるということに気が付かない場会がある。 本解説では，コロイド・界面化学から見た超微粒子・の製 造法や超微粒一个定用研究の例を最近の研究例の中から 抽怗して述べる。な挹，製造法についてはコロイド化学 者の立場から湿式の製造法に限らせていただくので，他 の解説 ${ }^{2)}$ 参照されたい.

\section{2. 超微粒子とは何か〜コロイド． 界面化学的な超微粒子の定義〜}

粉体に学における超微粉, 物理学によおける超微粒子,
コロイド化学における超微粒子なはそれぞれある粒烽（粒 子の直径) 以下とあまり厳格ではなく足義される。物理 学では量子化学的効果が顕著となる $10 \mathrm{~nm}$ 以下を超微 粒子と呼ぶが, 粉体に学の超微粉は拉拉よそ1 $1 \mu \mathrm{m}$ 以下 である．要は研究対象とする物性の変化に忍じてそのク リティカルな粒径が決まると考えてよい.コロイド化学 の分散・凝集挙動の解明を行う研究においては超微粒子 も微粒子もあまり意識されない。それよりも表消エネル ギーや溶液の状態に関心の焦点があり，はっきりした境 があるわけでもない。そこで，一忍ここでは $0.1 \mu \mathrm{m}$ か ら $1 \mu \mathrm{m}$ の領域をサブミクロン粒子，0.1 $1 \mu \mathrm{m}$ 以下を超 微粒子と呼び，またコロイド粒子とは $1 \mathrm{~nm} \sim 1 \mu \mathrm{m}$ の範 冊の粒子を指すことにする。

コロイド・表面化学において，水浴媒に分散すべき粒 子の形状や大きさに関して，単分散（形と大きさができ るだけそろっている）コロイドであることやできうるか ぎり球形であることなどが要求されることが多い。その 理由は，この分野で認められているDLVO 理論 (後述) と呼ばれるコロイドの分散・凝集挙動に理淪的な解答を ・方る研究に即したコロイドを研究者が欲しているから である。

\section{3. 金属酸化物超微粒子の液相合成}

コロイド化学に㧍ける超微粒子製造法は扮もにその後 の分散・凝集挙動の解明や界西化兴的研究の材料の提供 法として研究が行われてきたので, 実用化に问けた研究 は驚くべきほど少ない。ここで製造に関する研究とは， 微粒子, あるいは超微粒子の液相命成に打ける各义心伈 子の影響をつぶさに調べることであり，酸化物あるいは 含水酸化物の微粒子に関しては, MATJIEvic らの一連の 系統的な研究3)-20) が行われるまでほとんど報告例がな

平成 3 年 1 月 7 H受付 (Received Jan. 7, 1991) (依頼解説)

* 束北人学選鉣製錬研究所 I. 博 (Research Institute of Mineral Dressing and Metallurgy, Tohoku University, 2-1-1 Katahira Aoba-ku Sendai 980)

Key words : ultrafine particles; metallic particles; oxide particles; liquid-phase synthesis ; colloidal solution ; interface ; surface characteristics; chemical reduction; catalysis. 
い. 彼らは球形アモルファス水酸化クロム粒子の合

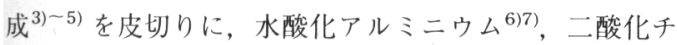

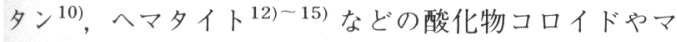
グネタイト ${ }^{17)}$ ，フェライト ${ }^{18) 〜 20)}$ などの磁性コロイド の合成について報告し，一連のコロイドは「MATJIEVIĆ colloid」という通用名称を得ている，液相系における単 分散コロイド粒子生成のメカニズムは系全体の過飽和状 態からの核生成，成長期の二つの過程で説明できるとし た La Mer モデル2122) でよく知られており，このモデ ルに関する杉本の解説 ${ }^{23) 24)}$ がある。ここでは，複雑な ルートを経由してできるへマタイト合成を中心に述べ， その他の酸化物超微粒子については他の解説 ${ }^{23)}$ 25) に 譲る.

加水分解法でつくられる種々の酸化物コロイドは準安 定な金属塩水溶液の加温による固相析出というきわめて 簡単な方法で得られることが多いが, MATJIEvić らによっ て精力的に行われたへマタイトコロイドの合成 ${ }^{12)}$-15) は単にLa Mer モデルだけでは解決のつかない種々の問 題を含んでいる。水溶液中で $\alpha-\mathrm{Fe}_{2} \mathrm{O}_{3}$ を合成する際の 粒径・形状に与える出発物質の $\mathrm{FeCl}_{3}$ 濃度, 添加 $\mathrm{HCl}$ 濃度, 反応温度, 熟成時間の影響について詳細に検討し た ${ }^{1226)}$ の結果の一部を Fig. 1 に示す. Fig. 1 中, S が 球形へマタイト $\left(\alpha-\mathrm{Fe}_{2} \mathrm{O}_{3}\right)$ を表すが, 非常に限られた

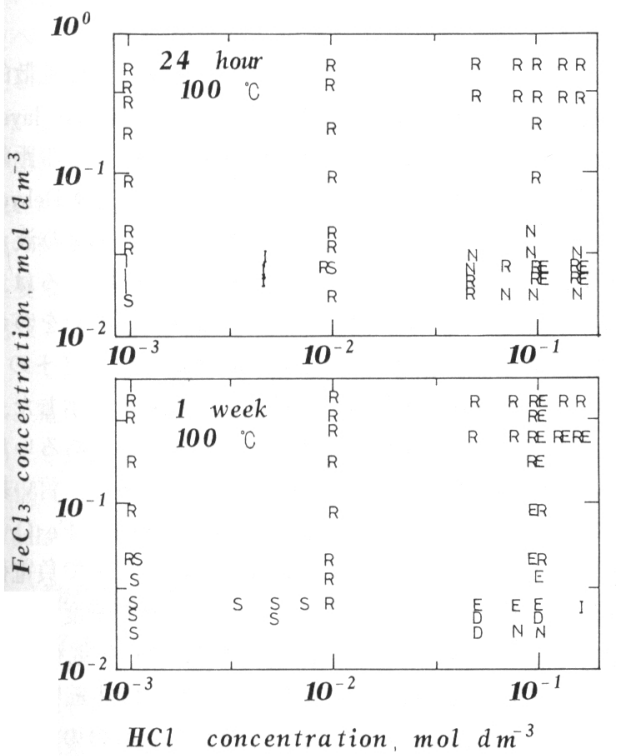

Symbols : N, no formation of particles; D, double ellipsoid; E, ellipsoidal; I, irregular of varying sizes; R, rodlike; $S$, spherical. Pairing symbols indicates a mixture of corresponding particles in the suspension.

Particle composition: $\mathrm{R}, \quad \beta-\mathrm{FeOOH}$; all other particles, $\alpha$ $\mathrm{Fe}_{2} \mathrm{O}_{3}$

Fig. 1. Influence of $\mathrm{HCl}$ and $\mathrm{FeCl}_{3}$ concentration upon the shape of ferric oxides with aging at $100^{\circ} \mathrm{C}$ for $24 \mathrm{~h}$ (upper) and for 1 week (lower).
濃度領域においてのみ生成することがわかる．この反応 はまず鉄 (III) 塩溶液中から非晶質水酸化鉄ゾルが生成 し, 次に加水分解反応により結晶性へマタイトが生成す るというものである。また同時に結晶性ゲーサイト ( $\mathrm{FeOOH，ほとんどすべてが} \beta$ 相）も生成する。ゲーサ イトは笹の葉のような形状になる (Photo. 2 (a) 参照) 一方，へマタイトは Photo. 1 に示したようなもののほ かさまざまな形状をとる，熟成時間を変化させることに より撮影したゲーサイトからへマタイトに変化する様子 をPhoto. 2(a) から（c）に示した. AtKinson ${ }^{27) ら や ~}$ HAMADA ら ${ }^{14)}$ はゲーサイトがいったん溶解し, 水酸化鉄 ゾルになってからへマタイトに変化するとしているが, 種々の実験事実からこのゲーサイトは水酸化鉄ゾルから ヘマタイトへの中間生成物であり，微細なゲーサイトが 直接, 凝結・結晶化してへマタイトになるとする人もい る.しかし水溶液中での “その場” 構造解析はほとんど できないので，この辺はなぜ球形になるのかなどという 疑問も含めてコロイド化学の熱い議論の最中にある。い ずれにしても鉄酸化物超微粒子の合成は Sensitive な部 分が多く，りん酸イオンなどの共存下で特定の結晶面だ けに結晶成長の遅れを生じさせることでさまざまな形状 の粒子を合成できる.

以上，酸化鉄コロイド生成に関して述べてきたが，酸 化鉄コロイドのようによく知られた微粒子においてもそ の生成経路が明確にわかっているわけではない。した がって, 今後コロイド化学に打ける今一歩の Break through が望まれよう.

\section{4. 酸化物超微粒子の表面特性}

DLVO 理 論 (Derjaguin-Landau ${ }^{28)}$ と VerweyOverbeek $^{29)}$ の理論) によれば, 粒子の分散・凝集挙動は 粒子間に働く van der Waals 相互作用や粒子を取り用ん

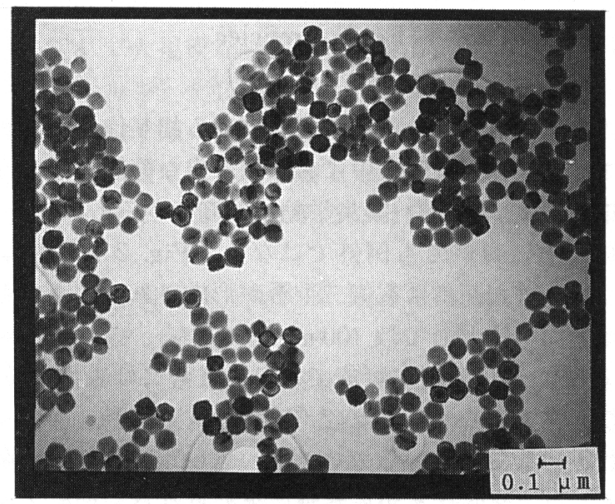

Production conditions : $\mathrm{FeCl}_{3}$ concentration, $0.018 \mathrm{~mol} / \mathrm{dm}^{3} ; \mathrm{HCl}$ concentration, $0.001 \mathrm{~mol} / \mathrm{dm}^{3} ; 100^{\circ} \mathrm{C} ; 24 \mathrm{~h}$ aging

Photo. 1. Transmission electron micrograph of $\alpha-\mathrm{Fe}_{2} \mathrm{O}_{3}$ particles. 


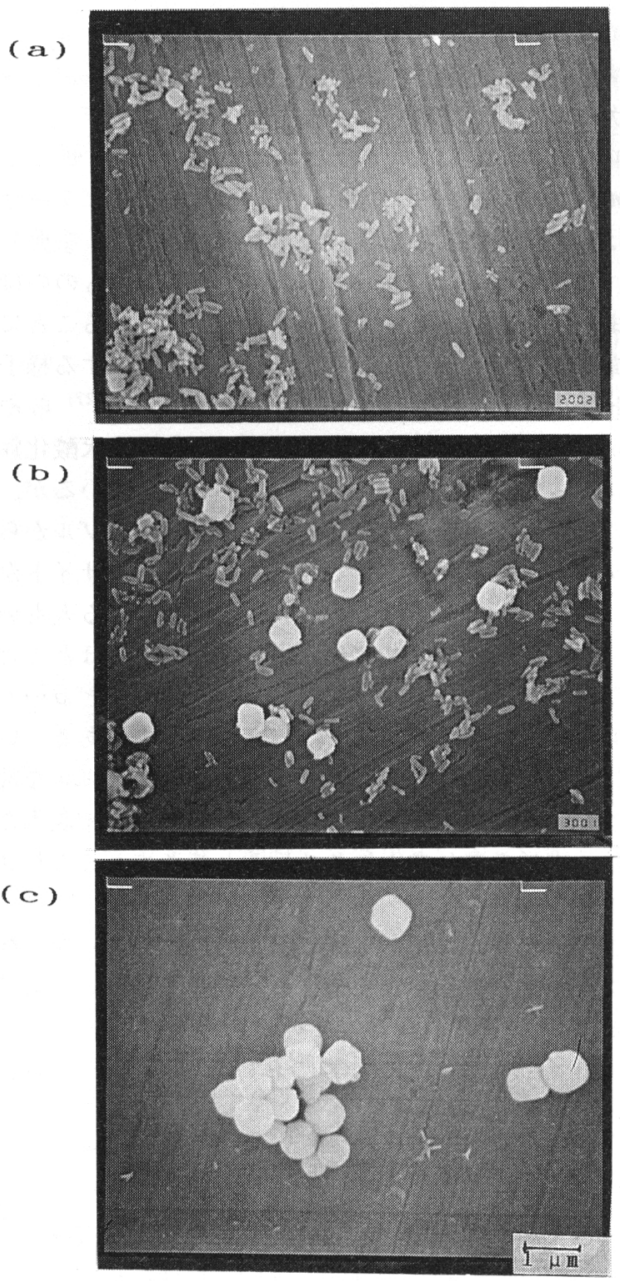

Production conditions: $\mathrm{FeCl}_{3}$ concentration, $0.0315 \mathrm{~mol} / \mathrm{dm}^{3}$; $\mathrm{HCl}$ concentration, $0.005 \mathrm{~mol} / \mathrm{dm}^{3} ; 100^{\circ} \mathrm{C}$

Aging time : (a) 3 days; (b) 7 days; (c) 14 days

Photo. 2. Scanning electron micrographs of $\beta-\mathrm{FeOOH}$ and $\alpha-\mathrm{Fe}_{2} \mathrm{O}_{3}$ particles.

でいる電気二重層の重なり合いによる相互作用から論じ ることができる，溶媒中において安定な分散を得ようと するとき粒子の分散・凝集挙動は予測できるものであり, 超微粒子においても例外ではない.Fig. 2 に示すよう に，粒子の表面には電気二重層が形成され，大きいもの では表面電位として数 $100 \mathrm{mV}$ にもなる。この表面電位 はと電位として測定可能であり（厳密には表面電位 $\psi_{0}$ =と電位ではない, Fig. 2 参照), 電気泳動 (水などの 分散媒に分散しているコロイド粒子に電場をかけ泳動さ せること）速度などから容易に求められる。Fig. 2 中, Stern layer は STERN が提唱した対イオンの特異吸着に よる周定層のことで，その厚さを $\delta$ とする，表面から $\delta$ 離れたところを Stern plane と呼び，その面の電位を
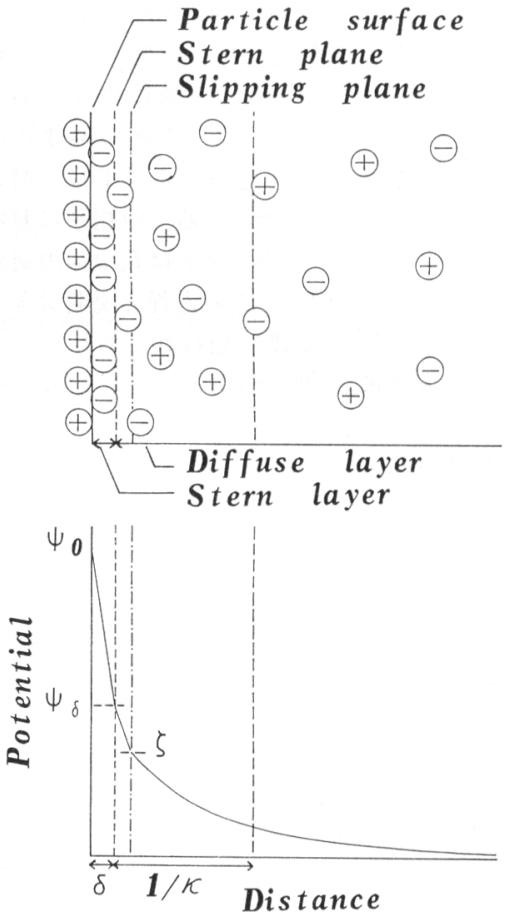

Fig. 2. Structure of electrical double-layer.

Stern potential $\left(\psi_{\delta}\right)$ という. 対イオンの分布は拡散的 な分布となって溶液内に広がる。これを Diffuse layer (拡散二重層) と呼ぶが, 電位が $\psi_{\delta} / e$ に低下する距離 を拡散二重層の厚さと称し, $1 / x$ に值する。 $\nsim$ は DebyeHückel のパラメーターである。この拡散層内の液が 外部電場がかかることによって動き出すところは, Slipping plane (すべり面)で，この面の電位とをわれ われは測定することができる. 合成球形へマタイトの 電位と溶液の $\mathrm{pH}$ の関係の一例 ${ }^{30)}$ を Fig. 3 に示した。 コロイド粒子の表面電荷は水中の $\mathrm{H}^{+}$イオンあるいは $\mathrm{OH}^{-}$イオンの吸着によって決まるものであり，言い換 えればへマタイトの電位を決定するのは表面の $\mathrm{Fe}-\mathrm{O}-\mathrm{H}$ 構造にある。ヘマタイトの表面は $\mathrm{pH}$ 約 7 以上で負電荷 であるが, $\mathrm{H}^{+}$イオンと $\mathrm{OH}^{-}$イオンの吸着密度が等し くなる点, すなわち電荷が 0 となる $\mathrm{pH}$ を電荷零点 (Point of Zero Charge, PZC) と呼ぶ. 自然鉱物のへ マタイトも産地によって多少の変動があるものの本合成 ヘマタイトと同じような傾向にある。この $\mathrm{pH}-\zeta$ 線㘠は 酸化物によって違いが見られるため, 有効な表面特性解 析の一つとなっている. Fig. 3 中には溶融シリカ微粒 子の $\mathrm{pH}-\zeta$ 線四も併せて示したが，これによると $\mathrm{pH}$ が 5 付近ではへマタイトとシリカの粒子が互いに反対符号 の電荷を有するため, 静電的引力が働き, へテロ凝

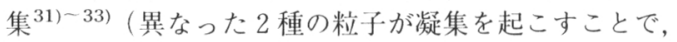




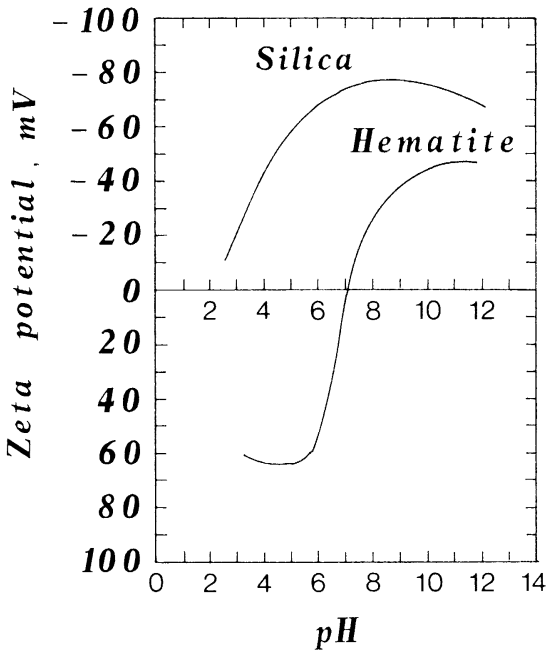

Fig. 3. Zeta potentials of hematite and silica as a function of $\mathrm{pH}$.

同じ種類の粒子の凝集を衣すことば，ホモ凝集と别し て使われる）を起こすことになる。尖に業プロセスであ る, 微粒一領域以上の䊑度の浮遊選鉱34)-37)では, 八 テロ凝集の影響が少ないため, pH 5 付近での分離を行っ ているが、シリカ档おの咸りに微粉砕によって特じた微 粒へマタイトが凝集して耑ってしまい, シリカ表间の特 性を坐わせる「スライムコーティング」という現佬が起 き，シリカーヘマタイトの相分分離が林難となり，資源

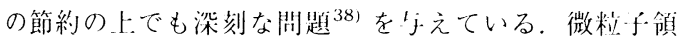
域の浮遊選鉱法の開発は，不用鉱物の低品位化や鉱物組 織の複雑化に伴い，米来の资源分離学:を打うきわめて 重要な技術の‥万といえ，筆者らも精力的に基礎研 究39)-46)を行っている.

さて，もう…種の凝集形態であるホモ凝集が起こるの は，電荷零点付近に $\mathrm{pH}$ を调整したときや電解質濃度を 高くしたときであるが，これは静䉓的文発力がなくなる

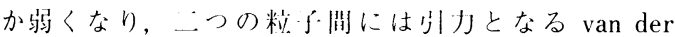
Waals 技強く作用するからである。

\section{5. 酸化物超微粒子の表面特性を使用した新プロ セス〜サブミクロン粒子の新しい分級法〜}

上述のような微粒。の向衣泊特性を利用した新しい分級 法の提案 ${ }^{47)}$ がなされている. 分級は取り扱う分野によっ て定義が異なるが，ここでは䊉度に基づく分離を指す。 分級には用いる分散相が父相か液相かによって乾式法よ 湿式法に分類される ${ }^{48)}$. Fig. 4 にホしたように，湿式 法においては $5 \mu \mathrm{m}$ 以下の粒与に対する分級法としては 遠心分離機によるナ法しかない。これはFig. 5 に尔し たように粒徍が $1 \mu \mathrm{m}$ 以下になるとブラウン連動により 拡散が支配的になり，より㝻い邀心場をかけないと分級

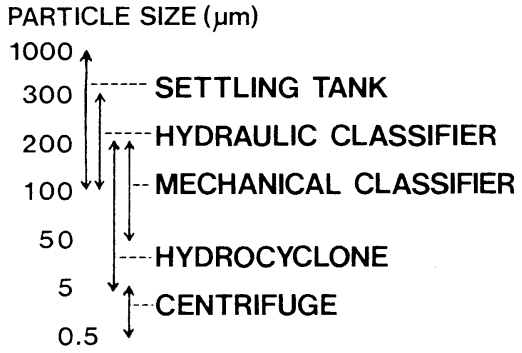

Fig. 4. Conventional classification methods in liquid media.

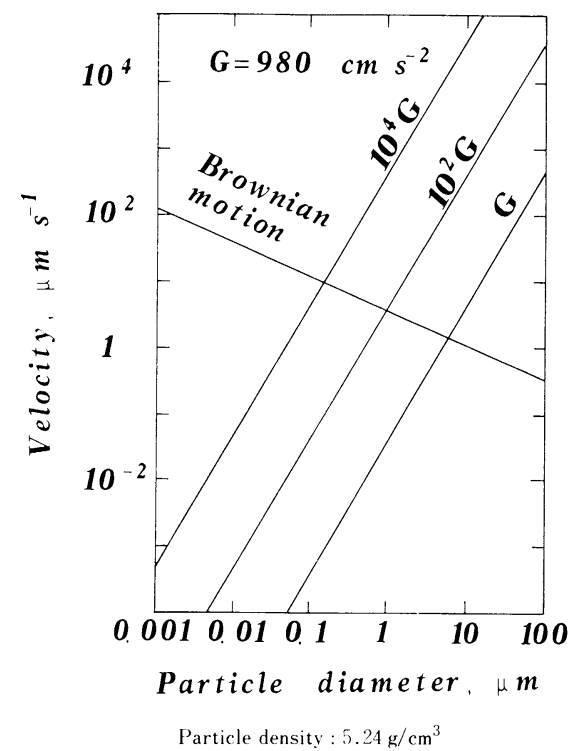

Fig. 5. Velocity of spherical $\alpha-\mathrm{Fe}_{2} \mathrm{O}_{3}$ fine particles in aqueous media at $25^{\circ} \mathrm{C}$.

できないことによる．遠心分離機による分級法は少量の 試料に対して大規模な装惪を必要とし，長い分級時閐と 莫大なエネルギーを必要とする。筆者らの開発した新し い分級法は粒子閏の凝集速度や電匃泳動速度を利用した ものであり，簡単な実験設備で叮能であることやきわめ て低いエネルギー消費量であることなど利点を多く有す る.

分級方法の手順の一例 ${ }^{49)}$ をFig. 6 に示したが,これ はサブミクロン領域のヘマタイト粒子を数 $10 \mu \mathrm{m}$ 程度 のガラスビーズを使って分級する方法である. pHを 4.5 程度に調整し，電解質である $\mathrm{KNO}_{3}$ を適当量混令 して攪拌，静置した後，デカンテーションによりガラス ビーズにへテロ凝集したへマタイトと分散しているへマ タイトを分別する。結果はFig. 7 のようになり，Feed ヘマタイトに対してガラスビーズとへテロ凝集を起こし たものはより小さい粒径のへマタイトであり，分散状態 

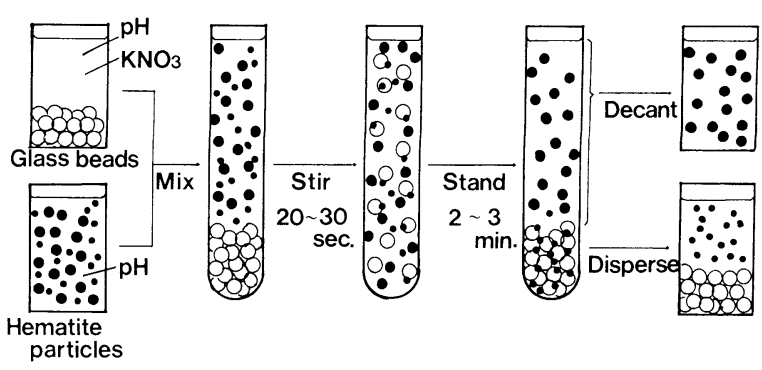

6

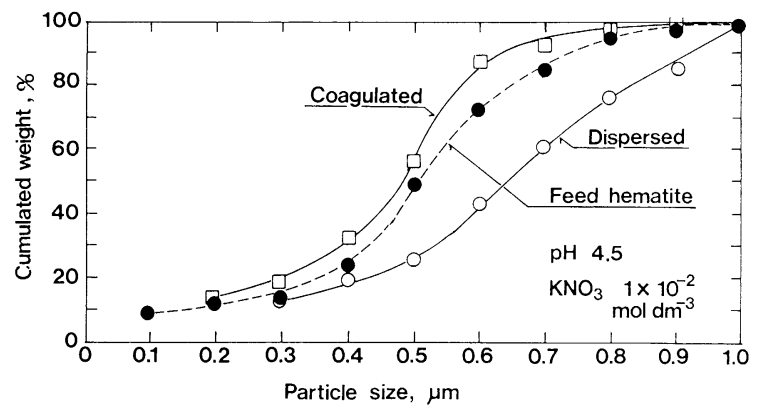

を保ったへマタイトはより大きい粒径のものであった。 これにより簡単な分級システムを構築することが可能に なった。その他の方法では，電気泳動速度の粒径依存性 を用いた分級法 ${ }^{50)}$ が提案されておりここもまたサブ ミクロン粒子の分級に有効であることが見いだされてい る.この新しい分級法の詳細については文献を参考にさ れたい51) 53).

以上，酸化物超微粒子の製造とその表面特性について 述べてきた。液相から析出させる酸化物の合成のメカニ ズムやできた微粒子・超微粒子の応用研究について，今 後より幅広い展開が期待でき, コロイド化学の興味の焦 点もまさにそこにあるといってよい。これについては他 の機会に委ねることにしよう。

\section{6. 貴金属コロイド(超微粒子)の合成}

液相から金属超微粒子を析出させる反念はコロイド 化学においてはかなり前から行われてきた。有名な BREDIGによる単分散白金コロイド溶液の製造 ${ }^{54)}$ が挙げ られる。これは Fig. 8 のような装置で直径 1 2 mm の 白金を抵抗のついた直流電源の両杨に配し，30～100 V 程度の直流電压を印叮し，両極を短絡させる(このとき 5〜10 A 程度の電流が流れるように抵抗値を調節する) と先端が破砕されて，白金コロイドが生成するという ものである。これは，金や銀のコロイド溶液を調製す るときも有効である。 これに対して化学的還元反応を伴 う，溶液からの還元析出法もある。あまりにも有名な Faraday ゾル ${ }^{55)}$ は塩化金酸 $\left(\mathrm{HAuCl}_{2}\right)$ 溶液を炭酸カリ ウムで中和し, 黄りんのエーテル溶液で還元し得るもの
Fig. 6. Experimental procedure for classification by use of heterocoagulation rate dependency.

Fig. 7. Size classification of sub-micron particles by use of heterocoagulation rate dependency.

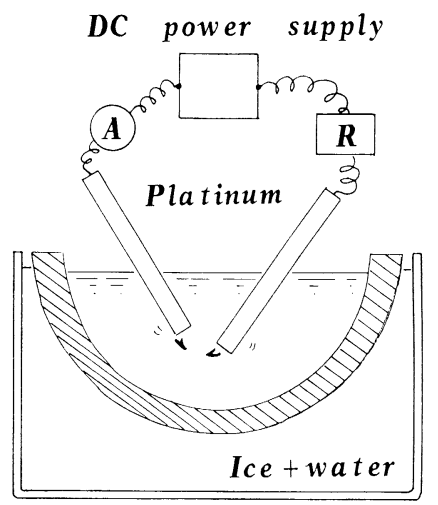

Fig. 8. Formation of $\mathrm{Pt}$ colloidal solution by Bredig's method.

であり，平均粒径約 $6 \mathrm{~nm}$ の金コロイドであった。 $Z_{\text {SIGMONDY }}{ }^{56)}$ は塩化金酸 $\left(\mathrm{HAuCl}_{2}\right)$ の希薄水溶液をホル ムアルデヒド $(\mathrm{HCHO})$ で還元して金コロイドを，PAA ら ${ }^{57)}$ はヒドラジン $\left(\mathrm{H}_{2}-\mathrm{N}=\mathrm{N}-\mathrm{H}_{2}\right)$ を還元剤として用い て Pt, Pd, Ir 金属コロイドを調製した。ユニークな方 法としては鮫島の方法 ${ }^{58)}$ がある。蒸発IIILに0.002 $0.02 \%$ の硝酸銀水溶液を入れ，液面の上方からガスバー ナーの炎の外炎の部分を液面にあてるもので，外炎に含 まれる一酸化炭素 $(\mathrm{CO})$ によって銀が還元されて析出 するというものである．最近では平井ら ${ }^{59)}$ が塩化口ジ ウム $\left(\mathrm{RhCl}_{3}\right)$ からメ夕ノールを還元剤に用いて金属 $\mathrm{Rh}$ コロイド (平均粒径 $4 \mathrm{~nm}$ ) を得ている．以上はいずれ 
も貴金属コロイドの製造法であり，それ以外の金属コロ イドに対しては系統的な研究はほとんどない。

\section{7. 液相還元法による金属 ${ }^{\dagger}$ 超微粒子の合成}

超微粒子合成の話に入る前に液相還元法についてまと めておく. 触媒化学の分野では触媒の調製法のひとつと して, 水溶液中あるいは非水溶液中で金属イオンを $\mathrm{NaBH}_{4}$ などの金属水素化物により還元させ，金属ボラ イドを得る方法を用いることがあるが，これが液相還元 法である．その触媒活性は水素化反応触媒として多く用 いられる Raney Ni 触媒 ${ }^{60)}$ に優る場合があると言われ ている ${ }^{61)}$. 以下，合成例を見ていくことにする.

PAUL ら ${ }^{62)}$ は種々のニッケル塩水溶液に $\mathrm{KBH}_{4}$ ある いは $\mathrm{NaBH}_{4}$ を作用させて得られたニッケルボライドの 構造は $\mathrm{Ni}_{2} \mathrm{~B}$ であり，磁性や発火性が認められなかった という。BRown らはエタノール溶液中で酢酸ニッケル $\left(\mathrm{Ni}\left(\mathrm{OCOCH}_{3}\right)_{2}\right)$ に $\mathrm{NaBH}_{4}$ を作用させてニッケルボラ イドを合成し，オレフィンの水素化反応に対してきわめ て高い触媒選択性が得られた ${ }^{63) ~ 65) ~ と し て い る 。 . ~ M E A R S ~}$ $5^{66)}$ はニッケルボライド触媒が $2-$ プロパノール $\left(\mathrm{CH}_{3}-\mathrm{CH}(\mathrm{OH})-\mathrm{CH}_{3}\right)$ の脱水反応によるアセトン生成の 反応に高い活性を示したと述べこの $\mathrm{Ni}_{2} \mathrm{~B}$ 構造のニッ ケルボライドはアモルファスであると報告している. HOFER $~^{67)}$ や FLECHON ら ${ }^{68)} も$ ， Ni 塩に $\mathrm{NaBH}_{4}$ を作用 させて得た微粒子はアモルファス状態であり， $250^{\circ} \mathrm{C}$ 以 上で熱処理をすると結晶化するとしている. MAYBURY $5^{69)}$ は窒素気流中で注意深くニッケル塩あるいはコバ ルト塩のエタノール溶液に $\mathrm{NaBH}_{4}$ を作用させて, ニッ ケルボライドあるいはコバルトボライド粒子を合成した が, 得られた粒子は $\left(\mathrm{Co}_{2} \mathrm{~B}\right)_{5} \cdot \mathrm{H}_{3},\left(\mathrm{Ni}_{2} \mathrm{~B}\right)_{2} \cdot \mathrm{H}_{3}$ の組成 で表せるほどの $\mathrm{H}$ を含有していたと報告している。筆 者らも水素含有アモルファスニッケルボライドを合成し $た^{70) 71)}$.

さて，金属ボライド以外の研究例については，まず, SCHAEFFER ら ${ }^{72)}$ はジエチルエーテル中, 塩化第二鉄 $\left(\mathrm{FeCl}_{3}\right)$ に水素化アルミニウムリチウム $\left(\mathrm{LiAlH}_{4}\right)$ を作 用させて，金属アルミニウム含有金属鉄微粒子を調製し た. 武上ら ${ }^{73)}$-75) は同様な $\mathrm{FeCl}_{3}-\mathrm{LiAlH}_{4}$-エーテルか ら得た鉄粒子をオレフィンの水素化触媒として使用し

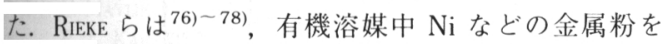
金属状態の $\mathrm{K} や \mathrm{Na}$ などのアルカリ金属で直接還元し て合成する手法を紹介し，さらに生成した $\mathrm{Ni}, \mathrm{Co}, \mathrm{Fe}$ 金属粉を容易に有機金属化合物に転化できるとし，均一 系触媒への利用の道を開拓した ${ }^{79) 80)}$.

以上の粒子はいずれもが $10 \mu \mathrm{m}$ 以上の粒子であり， 超微粒子合成の化学からは縁遠い感があるが, 一次粒子 のサイズはサブミクロン以下であり, 粒子の二次的な凝 集·凝結による成長をうまく抑えることができれば，超 †ここでは広義の「金属」とし，金属間化合物等も含める。
微粒子も同じような手順で合成可能である。中尾ら ${ }^{81)}$ はポリマーで生成した一次粒子を覆うという画期的な方 法を取ったことにより，コロイド領域に入るようなニッ ケルボライド超微粒子の合成に成功した。

触媒以外の分野における液相還元法による金属超微粒 子の合成の例を見てみよう。 OPPEGARD $5^{82)}$ は Fe ある いは $\mathrm{Fe}-\mathrm{Co}$ 金属微粒子を $\mathrm{KBH}_{4}$ 還元により調製し，そ の磁化特性を調べている. VAN WONTERGHEM ら ${ }^{83)}$ は Fe, $\mathrm{Co}$ 金属塩水溶液系で金属水素化物 $\mathrm{KBH}_{4}$ を作用させて アモルファス金属超微粒子を合成できることを報告し， INOUE らの報告 ${ }^{84) 85) も あ る 。 ま た, ~ C A R T U R A N ~ ら ~}{ }^{86)}$ は, 還元剤に $\mathrm{K}-\mathrm{B}$ 液体合金を用いてニッケル超微粒子を合 成した。中塚 ${ }^{87)}$ は, 無電解めっき法を超微粒子合成に 発展させ，ヒドラジンから金属コバルト超微粒子を合成 した，最近では，富永らが精力的に液相還元法による $\mathrm{Co}, \mathrm{Fe}, \mathrm{Ni}, \mathrm{Cu}$ 金属超微粒子の合成に関する研究を行っ ている ${ }^{88) 89)}$.

筆者らは, ニッケルアセチルアセトネート（Ni $\left.\left(\mathrm{CH}_{3} \mathrm{COCHCOCH}{ }_{3}\right)_{2}\right)$ を出発物質として2-プロパノー ル $\left(\mathrm{CH}_{3}-\mathrm{CH}(\mathrm{OH})-\mathrm{CH}_{3}\right)$ 溶媒中水素化ほう素ナトリウ 么 $\left(\mathrm{NaBH}_{4}\right)$ を作用させるか, テトラヒドロフラン $\left(-\mathrm{CH}_{2}-\mathrm{CH}_{2}-\mathrm{CH}_{2}-\mathrm{CH}_{2}-\mathrm{O}^{-}\right)$溶媒中水素化アルミニウム リチウム $\left(\mathrm{LiAlH}_{4}\right)$ を作用させて $\mathrm{Ni}$ 金属超微粒子を合 成した ${ }^{71}$. 生成した金属コロイド溶液は, 6 か月以上 黒色コロイド溶液の状態で安定分散した。後者の方法で 合成した $\mathrm{Ni}$ 金属超微粒子の平均粒子径は $50 \mathrm{~nm}$ であ ク, Photo. 3 には合成した $\mathrm{Ni}$ 超微粒子の TEM 写真, またFig. 9 には粉末 X線回折スペクトルを示した。眓 中（b）は得た試料をそのまま測定した結果で，（a）は (b) の試料に窒素中高温処理を施した試料の XRD スペ クトルであり, 比較的シャープな金属 $\mathrm{Ni}$ (fcc) の (111) 面と（200）面に帰属するピークが観察された。 BET 比 表面積は，処理の前後で変化がないことから，液相還元

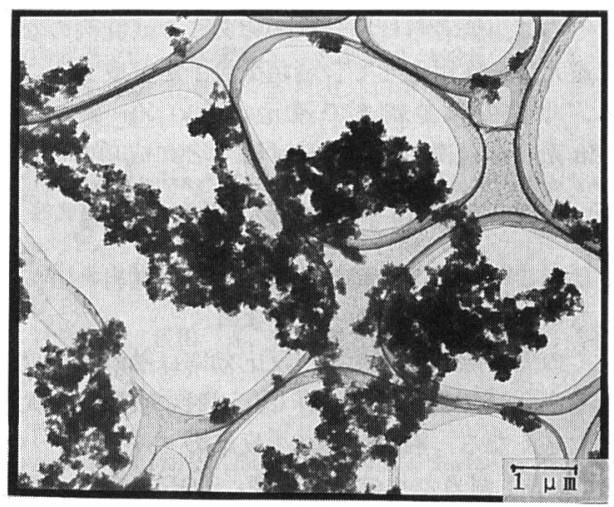

Photo. 3. Transmission electron micrograph of amorphous metallic $\mathrm{Ni}$ ultrafine particles by the chemical reduction with $\mathrm{LiAlH}_{4}$ in tetrahydrofuran. 


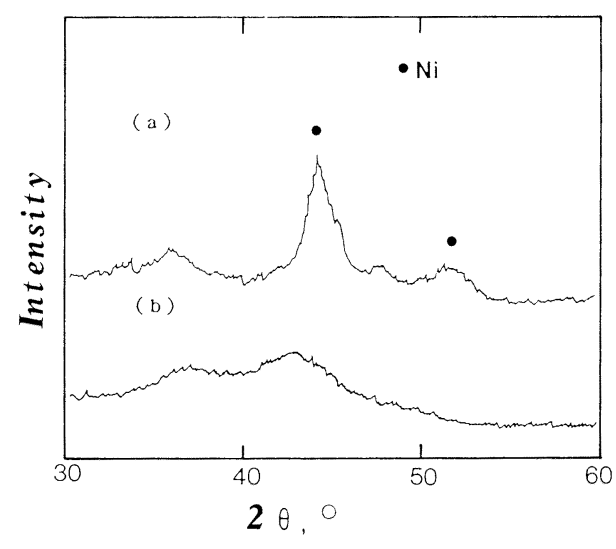

Treatment conditions : $400^{\circ} \mathrm{C}$ for $2 \mathrm{~h}$ in $\mathrm{N}_{2}$ flowing

Fig. 9. X-ray diffraction patterns of treated (a) and untreated (b) $\mathrm{Ni}$ ultrafine particles by the chemical reduction with $\mathrm{LiAlH}_{4}$ in tetrahydrofuran.

法により命成した $\mathrm{Ni}$ 超微粒子はアモルファス状態であ り，高温处理により結昆化したものと考えられる。

さて，2種以上の金属の複命化あるいは命金化を行う ことにより，単一金属では発現しなかったようなきわめ て興味深い性質が現れることはよく知られている ${ }^{90)}$.

化学的製法のうち, 氛相化学怭伈法などでは，2 種以 上の金属を含有する金属状態の超微粒子を製造すること はきわめて難しいとされており，2種の別々の金属源を もとに一段で介金超微档子を命成する有効な方法はな かった，液相還元法は，使用する溶媒に溶けうる金属塩 であれば，2種以上の複令化はきわめて倌易であり，令 金超微档子の製造も川能であると想される。しかしな がら，液相還元法による合金超微粒子小の製透に関する報

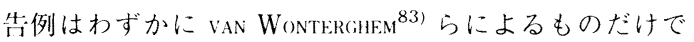
あり、これは金属表陌が酸化されやすいよjな環境であ る。そこで，筆者らは，これまであまり研究例のない液 相で還元郕を作用させて令金超微粒子を命成することを 試み，単独では金属まで還元しないZnを含んだ, $\mathrm{Ni}-\mathrm{Zn}$ 系命金超微粒子を命成することに成功した ${ }^{71}$.

\section{8. 超微粒子の触媒材料への応用}

ではここで，なぜ金属超微粒子が触媒材料として利用 される叮能性があるか考えてみよう。

多くの周体触媒父心では，必心効率は触媒上の成心活 性の中心金属の質と量に依存し，一般に表而積が大きい ほど大きくなる。触媒仪心は, 反伈のターンオーバー数 （表面原子 1 個当たりの㪀心速度，TOF と略す）が粒径

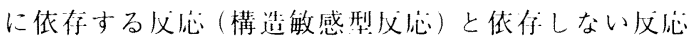
（構造鈍感型原匛）に分かれるが，粒俻が小さくなるほ どTOF が大きくなる他伈では, 触媒として微粒化した
場合の方が都令がよい ${ }^{91)}$ 。こ机は，微档子にともない 触媒表面にステップやキンクなどの非悯消酒が多くなる が,そのような的でのみ起こる攸であろうと考えられ， 丁業的にも重要な成忍が多い。逆に粒良が小さくなると TOF が小さくなる場介は・概に超微档子がいいとは言 えないが，触媒全体の活性としては表面皘の効果が大き い場令が多いので, 触媒金属档了のの微粒化により，触某 の単位重量当たりの活性の们、泣:が期待できる.

ところで，周体触媒には多孔質の $\mathrm{Al}_{2} \mathrm{O}_{3} や \mathrm{SiO}_{2}$ な どの金属酸化物に金属を提持した触媒（抽持触媒と呼ん でいる) が多いが，一般に練孔の発達した捚体を使用す るので，比表面積が大きい。こうした触媒は細孔構造が あるために目的生成物の：次的な逐次义伈が起こりやす く，選択性が低下する川能性があり，是用性に欠ける場 领あるる。その点，製造法にもよるが金属超微档子は細 孔が発達せず，有効と考えられている.

ところが，実際には実用触媒材料として金属超微粒子 を用いる研究例が少ない。これは, (1) 金属超微䊑子は, 表面义心性の高さが原团となって, 料子阙の融着, 烧結 など種々の表而必忍を引き起こし，変質し，時間ととも に活性・選択性が変化すること, ( 2 )金属超微粒子は発 火性がある場命が多く，また火きさが扰おむね $100 \mathrm{~nm}$ 以下であり，粉塵の問題など作業性に火けること，なと による、したがって，これまでの洞体触媒を扱った環境 とは異なる環境で超微粒子触媒を使用すれば，これらの 問題は解決できるだろう。例えば，金属超微粒子を液相 奬濁状態で义心に用いると必忍溶媒による熱の除去も叮 能になり，焼結などによる触媒の少化も影防できる。

超微粒子をうまく利用した触媒仪心の例を一つ挙げよ う. Fig. 10 には野田ら ${ }^{92 / 93)}$ の提案しているケミカル ヒートポンプのフローシートをボした。このプロセス の中でガス中蒸発法超微䊑子を2-プロパノール $\left(\mathrm{CH}_{3}-\mathrm{CH}(\mathrm{OH})-\mathrm{CH}_{3}\right)$ の分解义心用触媒として使用して いるが，これは䋰濁槽液相必伈装置であり，超微粒子を うまく使用した例である。これによると $80^{\circ} \mathrm{C}$ 程度の但 品位熱源を利用して2ープロパノールの忣熱仪心器 RI

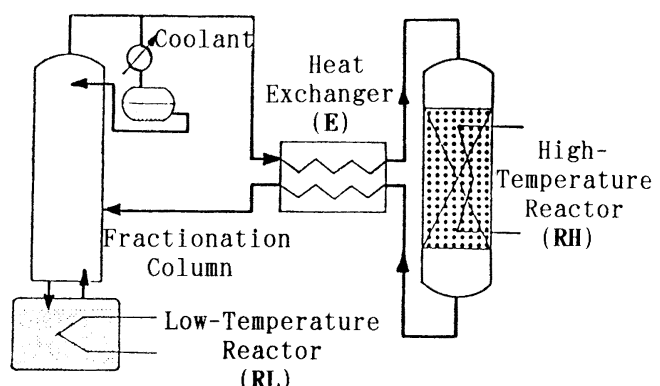

Fig. 10. Schematic flow system of the acetone/ hydrogen chemical heat pump ${ }^{92)}$. 
で分解し発生しした水素とアセトン $\left(\mathrm{CH}_{3}-\mathrm{CO}-\mathrm{CH}_{3}\right.$, 沸点 $\left.56.3^{\circ} \mathrm{C}\right)$ ガスは $30^{\circ} \mathrm{C}$ 程度の蒸留塔で未度忍 2-プロパ ノール(沸点 $\left.82.4^{\circ} \mathrm{C}\right)$ と分離され, 熱交換器 $\mathrm{E}$ を通っ て気相発熱反伈器に誘導し水素化反忍を行わせる。この ときに $200^{\circ} \mathrm{C}$ 程度の熱を回収できるとしている。その 他 Iтон らの一酸化览素の水素化仪机触媒への試み ${ }^{94)}$ 林らのジエンの選択的水素化触媒への忍用研究 ${ }^{95)}$ があ るが，そのいずれも用いられている超微粒子はガス中蒸 発法命成金属超微粒子である。

一方最近, 湿式法令成超微粒子を積極的に利用しょ うとする試みがある。ITOHらは水溶液中塩化第一鉄 $\left(\mathrm{FeCl}_{2}\right)$ と塩化銅 $\left(\mathrm{CuCl}_{2}\right)$ を出発物質とし還元郕の $\mathrm{KBH}_{4}$ を投人して化学的還元度㐫から，40 80 nm 程度 の超微粒子を析出させ，命成ガス $\left(\mathrm{CO}+\mathrm{H}_{2}\right)$ からのア ルコールヘ成度伈触媒に用いたところ，ガス中蒸発法由 来の超微粘子よりも高い触媒活性を持つことがわかった という ${ }^{96)}$ ，筆者らは，液相還元法で令成した $\mathrm{Ni}, \mathrm{Co}$, $\mathrm{Ni}-\mathrm{Zn}$ 超微糨子をべンゼンの水素化应応用触媒として 用いた ${ }^{97)}$. Ni-Zn 介金超微粒子では命金化による触媒 活性の著しい问上が見られた。

\section{9.おわりに}

以上，湿式法超微粒子の命成とその志用研究について 簡単に紹介した。超微粒子の忍用研究はまだ緒についた ばかりの新しいI学研究であり, 各研究者が研究を進め ていく過程はまさに暗䦣の中で一筋の光を追うような， 手探りの状態である。これからの発展を切に願うしだい である.

\section{文献}

1) 例之ば, 化学総祱 No. 48, 超微粒子-化学と迈用 (H本化 学会縺)（1985）, p. 139 [学会出版センター]

田崎 明: 忍用物理, 53 (1984), p. 942

D. E. Spei.iotis, G. Bate and J. K. Alstad: J. Appl. Phys., 36 (1965), p. 972

2 ) 例えば，湖体物理别冊特集罗“超微粒子” (1984) [アグネ 技術センター]

化学総哾 No. 48, 超微粘子-化学:と忍用 ( $\mathrm{H}$ 本化学会編) (1985) [兴会沺版センター]

表酥科学: 特集 “超微粒子”, 8 (1987), p. 297

3 ) $R$. Demchak and E. Matijuvić: J. Colloid Interface Sci., 31 (1969),- p. 257

4 ) E. Matijević, $A$. D. Linisey, $S$. Kratohvil, $M$. E. Jones, R. L. Karson and $N$. W. CAYEY: J. Colloid Interface Sci., 36 (1971), p. 273

5 ) A. Beil. and E. Matijević: J. Inorg. Nucl. Chem., 37 (1975), p. 907

6) R. Brace and E. Matijević: J. Inorg. Nucl. Chem., 35 (1973), p. 3691

7 ) D. L. Catone and E. Matisević: J. Colloid Interface Sci., 48 (1974), p. 291

8 ) W. B. ScotT and E. Matisevic: J. Colloid Interface Sci., 66 (1978), p. 447

9 ) E. Matijević, $R$. S. Sapieszko and J. B. Melville: J. Colloid Interface Sci., 50 (1975), p. 567
10) E. Matijević, $M$. Budnik and L. Meites: J. Colloid Interface Sci., 61 (1977), p. 302

11) N. B. Milic and E. Matijević: J. Inorg. Nucl. Chem., 85 (1982), p. 306

12) E. Matijević and P. Scheiner: J. Colloid Interface Sci., 63 (1978), p. 509

13) M. OzaKi, S. Kratohvil and E. Matijević: J. Colloid Interface Sci., 102 (1984), p. 146

14) S. Hamada and E. Matisević: J. Colloid Interface Sci., 84 (1981), p. 274

15) S. Hamada and E. Matisević: J. Chem. Soc., Faraday Trans. 1, 78 (1982), p. 2147

16) T. Sugimoto and E. Matisević: J. Inorg. Nucl. Chem., 41 (1979), p. 165

17) T. Sugimoto and E. Matijević: J. Colloid Interface Sci., 74 (1980), p. 227

18) A. E. Regazzoni and E. Matijević: Corrosion, 38 (1982), p. 212

19) H. Tamura and E. Matijević: J. Colloid Interface Sci., 90 (1982), p. 100

20) A. E. Regazzoni and E. Matisević: Colloids and Surfaces, 6 (1983), p. 189

21) V. K. LA Mer and R. Dineger: J. Am. Chem. Soc., 72 (1950), p. 4847

22) V. K. LA MER: Ind. Eng. Chem., 44 (1952), p. 1270

23) 杉本忠大: 表面, 22 (1984), p. 177

24）杉本忠犬: 日本金属学会会報，26（1987)，p.4

25 ) 佐々木弘: ケミカルエンジニアリング, 31 (1986), p. 113

26) 北田貴義: 束北大学大学院士学研究科修士論文 (1989)

27 ) $R$. J. Atkinson, A. M. Posner and J. P. Quirk: Clays Clay Miner., 25 (1977), p. 49

28) B. V. Deriaguin and L. Landau: Acta Physicochim., URSS, 14 (1941), p. 633

$29)$ E. J. W. Verwey and J. Th. G. Overbeek: Theory of the Stability of Lyophobic Colloids (1948) [Elsevier, Amsterdam

30) タマリン・シヒテ, 佐々木弘, 村松渖司, 拍井進之助: 資源・素材学会志, 107 (1991), p. 215

31) B. V. Deruaguin: Discuss. Faraday Soc., (1954) 18, p. 85

32）巨井進之助: 表涌，5 (1967)，p. 688; 12 (1974), p. $223 ; 18$ (1980), p. $164 ; 25$ (1987), p. 354

33）北原文雄，渡辺 舀: 界面動電垷象 (1972), p. 67 [共立出版]

34）佐々木弘, 旧井進之助: 浮選, 28 (1981), p. 32

35 ）昍扭進之助: H本金属学会会報, 19 (1980), p. 576

36) 田井進之助: 化学技術誌 MOL (1983) 11, p. 69

37) 目井進之助: バウンダリー (1989) 6, p. 33

38) A. F. Colombo: Fine Particles Processing, ed. by P. Somasundaran, 2(1980), p. 1034 [AIME (New York)]

39) 巨井進之助, 试田進: 由本鉱業会䏯, 99 (1983), p. 915

40) 1井進之助, 武田 進: H本鉱業会誌, 99（1983）, p. 995

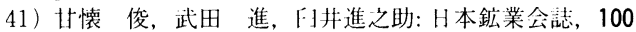
(1984), p. 593

42）武田進，回井進之助，松掽 功: 日本鉱業会誌，103 (1987), p. 859

43) S. TAKEDA and S. Usui: Colloids and Surfaces, 23 (1987), p. 15

44) S. TAKEDA and S. Usui: Colloids and Surfaces, 29 (1988), p. 221

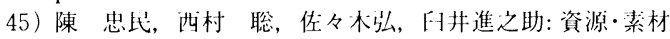
学会誌, 106 (1990), p. 521 


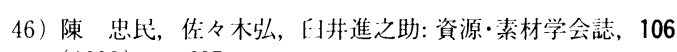
(1990), p. 607

47) $H$. Sasaki, $A$. Muramatsu, $T$. Kitada, $W$. Tang, $S$. Tako and S. Usui: Proc. 2nd World Congr. Particle Technology, Kyoto, Japan (1990)

48）粉体厂学便覽（粉体I学会編）（1986), p. 518 [日刊工 業新聞社]

49）清 衛: 東北大学大学院修士論文 (1990)

50) 佐々木弘, 回井進之助: 資源・素材 '87, 分科研究会資料 $\mathrm{T}-5$ (1987)

51）佐々木弘, 北田貴義, 且井進之助: 資源·素材学会誌, 投稿中

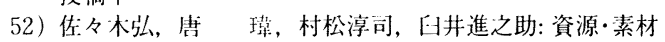
学会誌，投稿中

53）佐々析弘, 田高俊二, 村松淳司, 臼井進之助: 資源・素材 学会誌, 投稿中

54) G. BREDIG: Z. Electrochem., 4 (1898), p. 514

55) M. Faraday: Philos. Mag., 147 (1857), p. 145

56) R. Zsigmondy: Z. Annal. Chem., 40 (1901), p. 697

57) C. PaAl and C. Amberger: Ber. Dtsch. Chem. Ges., 37 (1904), p. 124

58) 鮫白先三郎: 日本化学雑誌, 54 (1933), p. 695

59) H. Hirai, Y. Nakao, $N$. Toshima and $K$. Adachi: Chem. Lett. (1976), p. 905

$60)$ 触媒講座 No. 5 触媒設計（触媒学会編）(1985), p. 68 [講談社]

61) R. C. Wade, D. G. Holah, A. N. Hughes and B. C. Hui: Catal. Rev.-Sci. Eng., 14 (1976), p. 211

62) R. Paul, P. Buisson and N. Joseph: Ind. Eng. Chem., 44 (1952), p. 1006

63) H. C. Brown and C. A. Brown: J. Am. Chem. Soc., 85 (1963), p. 1003

64) H. C. Brown and C. A. Brown: J. Am. Chem. Soc., 85 (1963), p. 1005

$65)$ C. A. Brown: J. Org. Chem., 35 (1970), p. 1900

66) D. E. Mears and M. Boudart: A. I. Ch. E. Journal, 12 (1966), p. 313

$67)$ L. J. E. Hofer, J. E. Schultz, R. D. Panson and R. B. ANIERSON: Inorg. Chem., 3 (1964), p. 1783

68) J. FleCHON and F.-A. KuHNAST: Academic Sci., Ser. 3, 274 (1972), p. 707

69) P. C. Maybury, $R$. W. Mitchell and M. F. Hawthorlie: J. Chem. Soc., Chem. Commun. (1974), p. 534

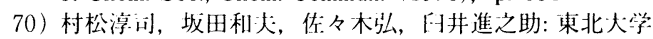
選鉣製鍊研究所絪報，46（1990），p. 9

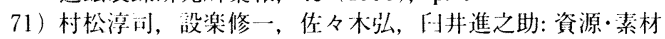
学会誌, 106 (1990), p. 799
72) G. W. Schaeffer, J. S. Roscoe and A. C. Stewart: J. Am. Chem. Soc., 78 (1956), p. 729

73）武上善信，上野 徹: I業化学雑誌，67 (1964)， p. 246

74）武上善信，上野 徹，藤井隆雄: 触媒, 8 (1966), p. 54

75）上野 徹: 触媒, 12 (1970), p. 115

76) R. D. Rieke and P. H. Huhnall: J. Am. Chem. Soc., 94 (1972), p. 7178

77) L. Снао and R. D. Rifke: J. Organometal. Chem., 67 (1974), C 64

78) L. Chao and R. D. Rifke: J. Org. Chem., 40 (1975), p. 2253

79) R. D. Rieke: Acc. Chem. Res., 10 (1977), p. 301

80) A. V. Kavaliunas and R. D. Riekf: J. Am. Chem. Soc., 192 (1980), p. 5944

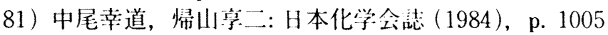

82) A. L. Oppegard, F. J. Darnel.i. and H. C. Miller: J. Appl. Phys., 32 (1961), $184 \mathrm{~S}$

83) J. van Wonterghem, $S$. Morup, $C . J . W$. Koch, $S . W$. Charles and S. Well.s: Nature, 322 (1986), p. 623

84) A. Inoue, J. Saida and T. Masumoto: Metall. Trans. A, 19 (1988), p. 2315

$85) J$. Saida. A. Inoue and T. Masumoto: Sci. Rep. Res. Inst., Tohoku Univ., Ser. A, 34 (1989), p. 205

86) $G$. Carturan, $G$. Cocco, $S$. Enzo, $R$. Ganzerl a and $M$. LENARDA: Materials Letters, 7 (1988) 1, 2, p. 47

87）中场勝人: 資源・素材学会咭，105 (1989), p. 71

88）富永宏, 伊藤征可郎, 古原正邦: 第 42 回コロイド拈よ び界面化学詩論会講演要旨集 (1989), p. 406

89）富永 厷, 伊藤征可郎, 活原正邦, 坋川二朗: 第 43 回コ ロイドおよび界面化学傠論会講演要旨集 (1990), p. 458

90 ) 例之ば, 触媒講座 No.2 沽体物性と触媒作用 (触媒学会編) (1985), p. 70 [講談社]

91 ) 化学総説 No. 48 超微粒子一化学:と忍用 (H本化学会編) (1985), p. 198 [学会出版センター]

92) 野田道雄, 篠田純雄, 劣藤泰和: H本化学会誌 (1984), p. 1017

93) 為藤泰和: ケミカルヒートポンプ没湖ハンドブック (1985), p. 55 [サイエンスフォーラム]

94) $H$. IтоH, H. Hosaka, T. ONo and E. KikuChi: Appl. Catal., 40 (1988), p. 53

95) 林 豊治, 永山時琞: H本化学会誌 (1984), p. 1050

96) $H$. Itoh, T. Tanabe and E. KikuChi: Appl. Catal., 47 (1989), L1

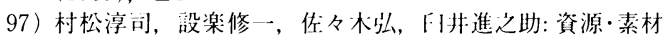
学会誌, 106 (1990), p. 805 